\title{
Cumbersome paths to indefiniteness: evidence from an Old Occitan Customary
}

\section{Complicados senderos hacia la indefinitud: evidencia a partir de un libro de derecho consuetudinario de occitano antiguo}

\author{
MiKOŁAJ NKollo \\ Universidad Adam Mickiewicz de Poznań, Polonia
}

\begin{abstract}
The central problem of this paper is the evolution of common nouns assumed to have turned into indefinite pronouns. The linguistic data have been retrieved from the Costuma d'Agen, a $13^{\text {th }}$-century Occitan Customary. The choice of this text is warranted by multiple relations obtaining between the architecture of legal codices and the presence of indefinite expressions. In this text the contexts in which re (< Lat. acc. REM), 'anything' or 'nothing' occurs have been identified. This word is shown to be pervasive in Negative Concord ( $\mathrm{NC}$; under the scope of no( $n$ ), the expression of clausal negation), thereby meeting the requirements imposed upon negative polarity items (NPIs). Outside NC, re appears in conditional protases and temporal clauses introduced by 'before'. Irrespective of the context in which it appears, Old Occitan re turns out to be fairly advanced on the grammaticalization scale: unlike its etymon, it no longer inflects for number, it does not take determiners and fails to function as a subject in the Costuma d'Agen. Comparative evidence from Gascon $13^{\text {th }}$ century texts proves that, although the descendants of REM of that period occur in the same structural environments (all of them are, by then, free-choice items, FCIs), they do not evolve at the same pace as their Occitan cognate. In other words, even in neighboring linguistic zones, these expressions differ with respect to the degree of persistence of syntactic properties inherent to Latin common nouns. Finally, re is matched against other FCIs, such as hom or home 'anybody' or 'nobody' and autrui 'someone else' or 'someone else's'. Compared to re, the medieval
\end{abstract}

Data de recepción: 10-09-2019 - Data de aceptación: 17-12-2019. 
developments of these items are far more diversified and retain more original features of their etymons. The difference is traced back to the greater conceptual salience of the animate domain.

Keywords: Old Occitan, negative concord, negative polarity item, free-choice semantics, indefinite, grammaticalization, legal texts.

Resumen. El problema central de este artículo es la evolución de los nombres comunes que se han convertido en pronombres indefinidos. Los datos lingüísticos han sido recuperados del Costuma d'Agen, un libro de derecho consuetudinario occitano del siglo XIII. La elección de este texto está justificada por las múltiples relaciones que existen entre la arquitectura de los códices legales y la presencia de expresiones indefinidas. En este texto se han identificado los contextos en los que aparece re (< lat. acus. REM) con valor de 'algo' o 'nada'. Se muestra que esta palabra es omnipresente en la Concordancia Negativa (NC; bajo el ámbito de no(n), la expresión de la negación clausal), de modo que reúne las exigencias impuestas a los ítems de polaridad negativa (NPIs). Fuera de NC, re aparece en prótasis condicionales y en cláusulas temporales introducidas por 'antes'. Independientemente del contexto en que aparece, el antiguo occitano re resulta estar bastante avanzado en la escala de gramaticalización: a diferencia de su étimo, no flexiona para número, no lleva determinantes y no funciona como sujeto en el Costuma d'Agen. La evidencia comparativa con los textos gascones del siglo XIII demuestra que, aunque los descendientes de REM de ese periodo aparecen en los mismos contextos estructurales (todos son, por tanto, ítems de elección libre, FCIs), no evolucionan al mismo ritmo que su cognado occitano. En otras palabras, incluso en zonas lingüísticas vecinas, estas expresiones difieren con respecto al grado de persistencia de las propiedades sintácticas inherentes a los nombres comunes latinos. Finalmente, se compara re con otros FCIs, tales como hom o home 'alguien' o 'nadie' y autrui 'otro' o 'de otro'. Comparados con re, los desarrollos medievales de estos elementos están mucho más diversificados y retienen más rasgos originales de sus étimos. La diferencia proviene de la mayor prominencia conceptual del dominio animado.

Palabras clave: occitano antiguo, concordancia negativa, ítem de polaridad negativa, semántica de elección libre, indefinido, gramaticalización, textos legales.

\section{INTRODUCTION: AIMS, METHOD AND DATA}

The paper is devoted to a well-known evolutionary path leading from nouns with a very general meaning to indefinite pronouns. The case under discussion involves context-induced shifts within, broadly speaking, the domains of negation and freechoice semantics. The central element brought under investigation is the Occitan re 'nothing / anything', derived from the Latin accusative REM 'thing'. Its occurrences, extensively documented in numerous medieval Occitan variants, will be analyzed in this paper. The language material has been collected from the present-day transcription 
of the Costuma d'Agen, a $13^{\text {th }}$-century legal codex from Agen, a town on the Garonne river (Department Lot-et-Garonne). The transcription task has been painstakingly carried out by Akehurst (2010), whose version is based on the MS42 manuscript from the Archives départementales de Lot-et-Garonne. The copy he worked with is known to have served for ceremonial purposes - people giving an oath in court used to place their hand on it. This is why the copy and the text have been referred to as the Livre juratoire. There is no particular stylistic or terminological refinement in the lexicon of the Costuma d'Agen (except for the units of measurement). Most of the words can be easily retrieved from general dictionaries (www.dom-en-ligne.de). The variety of Old Occitan documented in the Costuma d'Agen is sometimes called 'l'occitan juridique commun" (Bec 1987: 117). In what follows, the translations are by Akehurst, unless indicated otherwise. The interlinear glosses, designed to convey information about the meanings and grammatical features of individual words and their meaningful parts, have been prepared by the author ${ }^{1}$. In some cases, the author offers his own translations so as to convey particular grammatical properties more accurately. Translation and glossing of the Gascon material have been realized exclusively by the author.

Although southern France is considered the land of written law, many local communities had their own customary codices as well. Some of them were written down in compilations (customaries), which display an astonishing number of similarities to their northern French counterparts of the same period (Capin 2014: 66-67). In spite of a certain number of grammatical features specific of the geographical area (for example, future participles deriving from Latin forms ending in -urus have never been attested in Old French varieties), the availability of comparable types of texts in various areas is helpful for the present study: expressions recurrent in geographically diffuse communities can be easily observed in the same textual conditions to ascertain in what respects they represent common developments or whether they are, in fact, specific. Another less common facet of the present inquiry has to do with Old Occitan, a lesser studied Romance variety in comparison to its (oïl) French neighbor. The study is significant in that it provides a test case for some hypotheses about the diachrony of indefinites: how should the different phases of their development be reliably distinguished? Did the items deriving from common nouns, neutral with respect to polarity, travel freely back and forth between polarity types, or do they display a unidirectional development?

The glosses are based on the Leipzig Glossing Rules. Further abbreviations are given in a list at the end of this paper. 
To unravel these problems, an initial analysis was carried out manually. After the text had been read, all the instances of clausal negation were extracted. Their number was subsequently reduced by filtering out negations expressed uniquely with the aid of non or no (... lo senher del feus ges per aquo non pert sas vendas, ... XLVI, f. $78 \mathrm{v}$ ' $\ldots$ the lord of the fief does not on that account lose his sales tax'). In the remaining material, negative words other than no / non were given annotations according to their syntactic properties, and spelling variants they represent. From that stage on, the focus has been exclusively on re (a single occurrence of res, in the title of one of the chapters, has been found). Once all the occurrences of negative polarity re had been grouped together, an automatic query was launched to retrieve other structural environments in which it appears in the Costuma d'Agen. Further decisions were based on the dichotomy between the two types of syntactic contexts hosting re in the customary (i.e. in the scope negation or outside it). Thus, the main obstacle to overcome was to pinpoint the properties common to both usages.

To render the results of the analysis of $r e$ in the Costuma d'Agen more reliable, two further points are raised. First, Agen's data are matched against $13^{\text {th }}$-century Gascon (neighboring linguistic zone) cognates of $r e$ to see how expressions having a common origin were evolving in each of the varieties. Second, the outcomes of the evolution resulting in the re indefinite, as they are documented in the Costuma d'Agen, are compared with those of an erstwhile human-denoting common noun (HOMO > 'anybody, nobody'). The hypothesis is that, rather than having acquired the status of indefinite pronouns all at once, they evolved into free-choice items (FCI) first, no matter what particular polar value was involved.

The paper is organized as follows. Section 2 deals with generic nouns assumed to have turned into indefinite items, since this kind of evolution has been discussed in various descriptive and theoretical approaches. Accordingly, some of the properties of $r e$ are foreshadowed in traditional linguistics. In Section 3, the concept of Negative Concord (henceforth NC) is presented alongside its variants. In Section 4, a contextual analysis of re outside NC in the Costuma d'Agen is carried out. Special attention is paid to the multiple ways in which re is syntactically constrained in this particular configuration. Free-choice semantics is assumed to bring together various usages of $r e$ in both $\mathrm{NC}$ and non-NC contexts. Furthermore, Occitan $r e$ is matched against its Gascon counterparts. Section 5 concentrates on the relations between the semantic profile of $r e$ and discourse-pragmatic and grammatical characteristics of legal texts. The analysis makes use of the concepts of the Nähesprache 'language of proximity' vs. Distanzsprache 'language of distance' dichotomy propounded by Koch and Oesterreicher (2001). Section 6 discusses other expressions found in the Costuma 
d'Agen, which, by that time, were in the process of becoming indefinite pronouns. Section 7 summarizes the preceding observations.

\section{THE ORIGIN OF INDEFINITE PRONOUNS}

Heine and Kuteva (2002: 295-296) signal that the grammaticalization of the lexeme THING into an indefinite pronoun seems to be an instance of a more general process whereby generic nouns, i.e. nouns with a very general meaning, or "general ontologicalcategory nouns" in Haspelmath's (1997: 27) formulation, turn into pronominal categories. Evolutions along the same lines involve a series of other superordinate lexemes MAN; PEOPLE; PERSON; HOUSE. Examples of THING > indefinite and sentences illustrating the novel usage come from Swahili (kitu 'thing', noun > 'anything', 'something', when used in the object function) and Albanian (gjë 'thing' > indefinite pronoun). Nahuatl (itlaa 'thing' > tlaa 'something', indefinite pronoun) and Turkish (şey 'thing' > bir şey 'something'; lit. 'one thing') are additionally evoked. None of the examples given by Heine \& Kuteva (2002) in order to illustrate how THING is likely to change is straightforwardly assertive. The Swahili example is a negative sentence (Si-on-i ki-tu 'I don't see anything'), while the Albanian sentence (A ke gjë për të thënë? 'Do you have something to say?') is a YES-NO question.

An overarching functional distinction in the domain of indefiniteness involves two values: specificity i.e. "a unique token of a given referent type" (Schwenter 2014: 246) and non-specificity. In his comprehensive work on indefinite pronouns, Haspelmath (1997: 45) classifies indefinites according to whether they appear in specific or non-specific contexts and according to the type of polarity they represent (negative vs. non-negative). As a result, in his classification a subgroup of obligatory non-specificity inducing contexts is singled out:

i) perfective past, ongoing present (specific possible; non-specific impossible); no negative polarity;

ii) 'want', future, distributive (specific possible; non-specific possible); no negative polarity

iii) imperative (specific impossible; non-specific possible); no negative polarity

iv) question, conditional (specific impossible; non-specific possible); negative polarity

v) in the scope of negation (specific impossible; non-specific possible); negative polarity $^{2}$

2 Haspelmath's list is not exactly coextensive with information provided in the 'etymology' rubric of the entry for rien, in the Trésor de la Langue Française informatisé (TLFi; www.cnrtl.fr/ 
For the aims of the present paper, an important observation is related to the fact that, aside from sentences with an overtly expressed negative marker, two other contexts -questions and conditionals- are conflated within negative polarity. Thus, the subsequent analysis is supposed to reveal the distribution of $r e$ in $13^{\text {th }}$ century Occitan: was it likely to occur in any of the non-specific contexts, or, otherwise, was its distribution restricted to Haspelmath's negative polarity contexts? Do these contexts overlap or are they rigorously separate? An important prediction, inherent in texts such as the Costuma d'Agen, is that direct questions are virtually absent in legal texts.

Previous investigations into Occitan indefinites have also yielded some results with respect to $r e$. It is reported to transmit the positive and indefinite meaning in conditional, interrogative and comparative clauses, or, in structures that 'otherwise express doubt' (Jensen 1986: 178). The semantic value of $r$ enters the domain of negation, once it combines with the negative particle no. Unlike in the Swahili example cited above, this contextual effect is not specific of objects in the $o c$-speaking area. Occurrences of $r e$ in the subject function (taking, then, an overt declensional form surfacing as res) exhibiting the negative value are documented in Old Occitan, although none is found in the Costuma d'Agen. NPI in the glosses below stands for 'negative polarity item' (see next section):
(1) a. res de quant fan lui non es bon thing.NPI of how.much do.PRS.IND.3PL CL-DAT.3SG NEG be.PRS.IND.3SG good 'nothing of how much they do is beneficial to him'
b. res mas merces no $i$ es a dire, dompna
thing.NPI more.than mercy.SG.SBJ NEG=there be.PRS.IND.3SG to say.INF madam.SG.SJB 'nothing but mercy is to be said here, madam' (Jensen's examples; author's translations)

\section{NEGATIVE CONCORD AND NEGATIVE POLARITY}

Several concepts tied to the domain of negation need to be introduced first. Negative words (henceforth, $n$-words) are expressions that have the ability of being used in

etymologie/rien). Apart from outlining the evolution of rien towards negative polarity and its increasing co-occurrence with ne, the rubric enumerates contexts where this sign displays (or did so in the history of French) an indefinite non-negative and non-assertive value. All of these contexts are subsumed, following Martin's (1966) terminological choice, under the category phrases d'atmosphère négative: subordinate clauses introduced by ainz que 'before, earlier/sooner than' or sanz ce que, subordinate clauses following the main negative clause containing verbs of prohibition, $s i$-hypothetical clauses, relative clauses with an indefinite antecedent; YES-NO interrogatives, indirect interrogatives, comparisons of superiority / inferiority. 
response to specific questions (or QU-questions). This can be seen in present-day Catalan and Spanish examples:

(2) a. Qui ho ha dit? Ningú who ACC.3.M.SG AUX.3sg say.PTCP nobody 'Who said that? Nobody'

b. ¿Quien lo dijo? Nadie who ACC.3.M.SG say.PST.PRF.3SG nobody 'Who said that? Nobody'

Depending on whether the negative marker (i.e. the sign expressing clausal or sentential negation) is present or not, $n$-words in Romance languages can be further subdivided into negative polarity items (henceforth NPIs) and negative quantifiers (NQs). Unlike NPIs (3a), preverbal NQs express negation on their own (3b). This leaves open the question of whether a covert operator whose task is to induce NQs into acquiring the negative meaning is underlyingly present (Battlori 2019). Moreover, if numerous $n$-words are cumulated in a single clause, the resulting default interpretation is a simple rather than a double (or multiple) negation (3c). Thus, the negative meaning of the sentence is upheld throughout. This property accounts for the distribution of the [NEG] feature over an unrestricted number of expressions, provided they are under the scope of the negative marker or negative quantifier (Przepiórkowski \& Kupść 1997: 5).

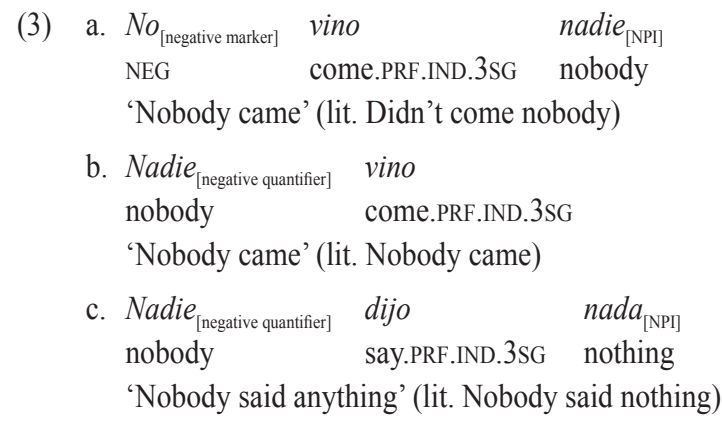

Negative concord (NC) is "the co-occurrence of more than one negative element in the same clause with the interpretation of a single instance of negation" (Zanuttini 1997: 9). Therefore, in this syntactic operation (Agree mechanism in Zeijlstra's 2004 terminology), two or more negative elements -the negative marker and the NPIare brought together to yield a single negation. NPIs fail to contribute independent semantic content to the negative statement. NC is needed, then, to enable speakers 
to assign NPIs the negative value and make them eligible in negative utterances. Unlike negative markers, which have an inherent [NEG] feature ${ }^{3}$, the negative value of NPIs is context-induced (Batllori 2019). The prerequisite for this contextual shift is the presence of an $n$-word under the scope of an anti-veridical operator (Horn 2016: 287-288). Basically, there are two of them: the negative marker itself and the preposition 'without' (Cat. Ho ha fet sense demanar ajut a ningú 'He did it without asking anyone for help'). If anti-veridical operators are present, $\mathrm{NC}$ is established via c-command (Batllori 2019).

In Romance languages, $\mathrm{NC}$ splits into two main types: strict and asymmetrical (or non-strict) negative concord. The difference between them "reduces to the featural make-up of the negative marker" (Zeijlstra 2007: 514). In the former type, a separate negative marker (in both conceivable configurations, i.e. negative marker - NPI or NPI - negative marker), is a prerequisite for a NPI to encode negation (Gianollo 2018: 155). In the latter, the negative marker is dispensed with altogether in some syntactic configurations. If used preverbally, $n$-words may become semantically negative, thereby advancing towards the status of NQs. Their non-inherent [NEG] feature is, then, activated. The negative marker is blocked in such circumstances (Martins 2014: 55-56). This model is found in present-day Portuguese, Spanish and Italian.

In NC, scope ambiguities are imminent, generally in response to the cumulation of multiple $n$-words. An interesting example, assumed to be the result of the nonreiteration of the negative marker non in the second of two coordinated conditional clauses, can be found in the Costuma d'Agen. Rather than being indicative of the positive polarity of creia re ('believe something'), the subsequent content points to the interpretation of $r e$ as 'nothing'.

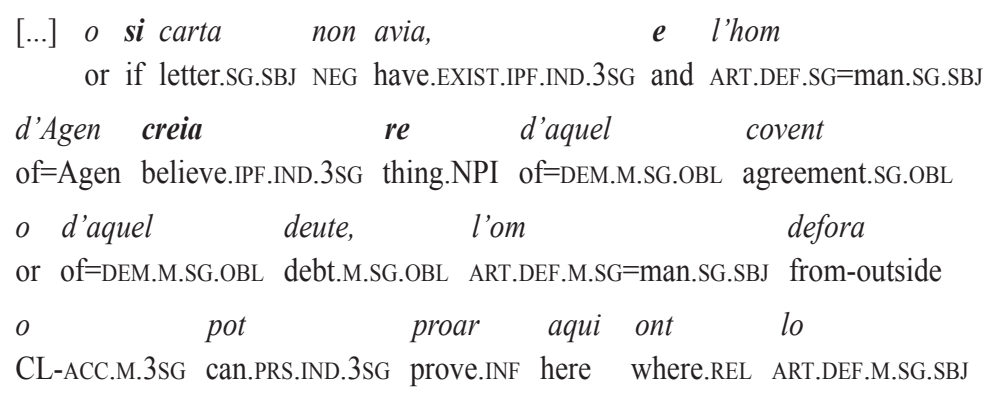

In so doing, they constitute so called anti-veridical contexts and create downward entailments; see Giannakidou (1998: 8), and note 5 below. 


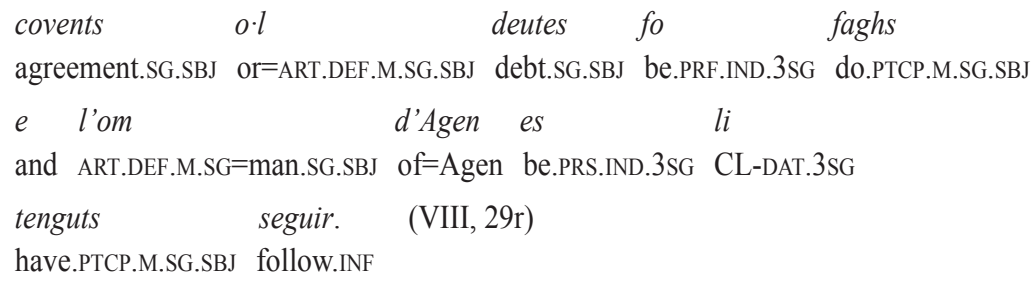

'[..] but if the written document were missing, and the man from Agen believed nothing / believed something (???) about this agreement or this debt, the man from outside can make proof of it at the place where the agreement or debt was made, and the man from Agen is obliged to follow him there.'

NPIs, including Occitan re, must not be confused with minimizers. The latter seem to originate from polarity-neutral expressions, whose role is to clarify the scope of the negation. Initially, they are added on an optional basis to the preverbal negative marker (Poletto 2016: 838-839). As for the Costuma d'Agen, it does not offer a single occurrence of $r e$ with the meaning 'at all, altogether'. Although Jensen (1986: 179) notes that in some of its adverbial uses re adds emphasis to the negation (thus expressing strong negation 'not at all'; res non sai ab qual mi tengua de n'Agnes o de n'Arsen 'I don't know at all which lady I should deal with, lady d'Agnes or lady d'Arsen'), one can easily imagine that a legal codex is not a favorable locus for this kind of emphatic expressions. In fact, there is nothing emphatic in those occurrences of re in the Costuma d'Agen, in which it corresponds with the basic negative no(n). Likewise, miga, ponch, reported to serve as minimizers in Old Occitan (Jensen 1986: $309)^{4}$, fail to display this value in the customary. By contrast, pas, although present, does not combine with $n o(n)+$ Verb. Instead, it appears in a contrastive negation (aquel feus era venduts [...] no pas propriament per aquel meiss deute ... 'this fief was sold not precisely to pay off the debt ...'; XXXIX, 69v), thus lending support to

$4 \quad$ Occitan minimizers denote items of insignificant size; miga or mica 'crumb'; pas 'step' and ponch 'point'. When combined with $n o(n)+$ Verb, they acquire the meaning of 'at all, altogether'. Perhaps, their status of negation boosters can be traced back to this primitive meaning of insignificance 'not even as much as a crumb, a step, a point', etc. Moreover, Gallo-Romance minimizers are thought to make up for the weak sound substance of no(n), the regular negation marker. Therefore, pas, miga or ponch appear whenever no(n) on its own might be considered too insubstantial. This is because negation is known to carry a heavy communicative load. It is an essential part of the message: if a hearer fails to recognize negation in the flow of an utterance, the intended message runs the risk of being fundamentally misunderstood (Dryer 1988: 99, 102). Moreover, the putative links between the primitive lexical meaning of the verb and the meaning of the nouns that serve as minimizers have been discarded as inadequate in Old French (Schøsler \& Völker 2014: 136-138). 
Larrivée's claim (2017: 460; see also Maiden \& Robustelli 2000: 404) that contrastive negation can only be expressed by a fully negative item.

In the Costuma d'Agen, re is an $n$-word in strict NC contexts only, which is tantamount to saying that it is never an NQ. Yet, one of its remarkable syntactic properties consists in its linear mobility with respect to the negative marker, which it can either precede or follow. Curiously, no $(n)$ remains mandatory even if the other putative anti-veridical operator senes que 'without' is present. In such configurations (5b), no(n) might be considered an expletive word (in keeping with the etymology of Lat. explere 'fill out', no merely fills out a sentence; see Vendryès 1950: 3-4).

(5)

a. mas si dints los ii. ans era

but if within ART.DEF.M.PL.OBL two year.PL.OBL be.IPF.IND.3SG

souts non deu re aver, e re

solve.PTCP.M.SG.SBJ NEG ought.PRS.IND.3SG thing.NPI have.INF and thing.NPI

plus demandar non deu. (XXXIX, 69r)

more demand.INF NEG must.PRS.IND.3SG

'but if within the two years it was released, he receives nothing, and may not sue for anything more.'

b. E si l'om pot escaper avantque

and if ART.DEF.M.SG=man.SG.SBJ can.PRS.IND.3SG escape.INF before $=$ COMP

sia pres, o apres, es quitis

be.PRS.SBJ.3SG catch.PTCP.M.3SG or afterwards be.PRS.IND.3SG acquitted.SG.SBJ

senes quel senher no.i a re ne

without COMP=ART.DEF.M.SG lord.SG.SBJ NEG=there have.PRS.IND.3SG thing.NPI nor

aquel hom non deu nassar neguna

DEM.M.SG.SBJ man.SG.SBJ NEG must.PRS.IND.3SG undergo.INF any.NPI.F.SG

pena. (XIX, f. 43v)

punishment.SG

'And if the man can escape before he is arrested, or after that, he is acquitted without the lord getting anything, and the man should incur no penalty.'

Even if deontic modality fails to be grammatically encoded in sequences such as no $\cdot$ i a re (lit. '[he] has nothing / not a thing there', with the simple indicative form $a$ 'has' in the apodosis), the deontic / injunctive meaning can easily be inferred on the basis of the very nature of legal regulations and the aims they are supposed to help achieve. 
In its NPI function, re has no syntactically dependent elements in its scope in the Costuma d'Agen. The only exception involves de-phrases (or their anaphoric substitutes), in which case re acquires a partitive value. This exception is thought to be in keeping with its free-choice semantics (no matter what part of father's possessions the addressee might choose; see Leonetti 2012: 294). At the same time, it lends support to Giannakidou's (1998: 141) 'licensing condition for negative polarity items': a negative polarity item is licensed if and only if the sentence is anti-veridical ${ }^{5}$.

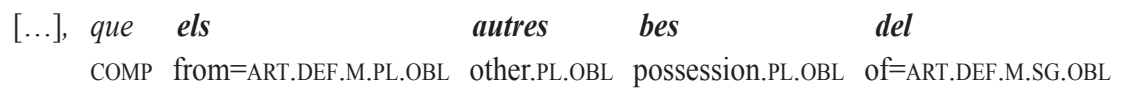

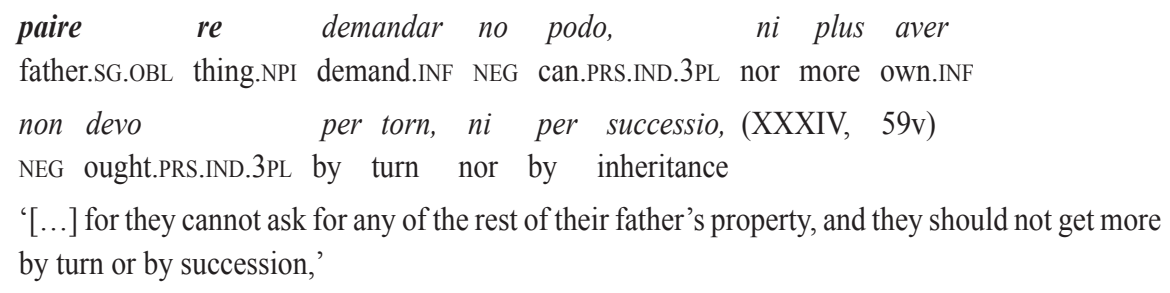

\section{RE OUTSIDE NEGATIVE CONCORD}

The remaining eleven examples prove to be more challenging. The detailed problem they pose is: are these non-negative contexts somehow syntactically constrained and semantically interrelated? The answer to this question may be expected to help describe the status of $r e$ in $13^{\text {th }}$-century Occitan with more accuracy. In the Costuma d'Agen, its distribution outside $\mathrm{NC}$ is restricted to two types of structures, in none of which re acquires the NPI status; i.e., the absence of the negative marker blocks the negative concord with $r$. The first of the two non-negative usages involves conditional protases: in (7b), re simply specifies some indeterminate part of a larger whole (re del loguer 'any amount of the rental'), thus acquiring once more an additional quantitative meaning. Example (7c) represents the conjunction of the hypothesis with the expression of exception (salb que si 'except if', 'unless'). In this sentence, re is a free-choice

$\overline{5}$ In yet another vein, the concept of 'downward entailment' is evoked to account for the distribution of NPIs (Denić, Chemla \& Tieu 2018). They are demonstrated to be systematically licensed in syntactic environments that allow for inferences from superordinate sets to subsets. For example, the sentence Anne didn't eat any vegetables today entails Anne didn't eat any eggplants today (where eggplants represents a subset of vegetables). In both sentences, the negative marker licenses the NPI any. It can be easily seen that neither does the entailment hold in the reverse direction (didn't eat any eggplants does not entail didn't eat any vegetables) nor does it extend over affirmative sentences, thus preventing any from appearing. Expressions that produce downward entailments for the NPIs, e.g. negative markers, are called licensors. 
indefinite 'no matter what, anything'. Syntactically, the analysis of the occurrences of re shows that in the Costuma d'Agen, it is never an agreement controller, irrespective of whether it contributes to the expression of negation or not.

(7) a. E si re en la maio l'estatgers

and if thing.FCI in ART.DEF.F.SG.OBL house.SG.OBL ART.DEF.M.SG.SBJ=resident.SG.SBJ

afolava, deu osmendar al

damage.IPF.IND.3SG must.PRS.IND.3SG CL-ACC.3.M.SG amend.INF to=ART.DEF.M.SG.OBL

senhor maio a la esgart del

lord.SG.OBL of ART.DEF.F.SG.OBL house.SG.OBL at estimate.SG.OBL of=ART.DEF.M.SG.OBL

cosselh (XXX, 55r)

council.SG.OBL

'And if the renter damaged anything in the house, he must make up for it to the owner at the estimation of the council'

b. $e$ si l'estatgers l'en deu

and if ART.DEF.M.SG.SBJ=resident.SG.SBJ CL-DAT.3sG=thereof owe.PRS.IND.3sG

re del loguer, no li es

thing.FCI of $=$ ART.DEF.M.SG.OBL rental.SG.OBL NEG CL-DAT.3SG be.PRS.IND.3SG

tenguts pagar, ni.l senher de

have.PTCP.M.SG.SBJ pay.INF and-not=ART.DEF.M.SG.SBJ owner.SG.SBJ of

la maio ni autre destrenher no

ART.DEF.F.SG.OBL house.SG.OBL and-not other.SG.SBJ force.INF NEG

l'en pot (XXX, 54v).

CL-ACC.3.M.SG=to-it can.PRS.IND.3SG

'and if the renter owes him any of the rent, he is not obliged to pay him, and neither the owner of the house nor anyone else can make him do so.'

c. e salb que si te a feus re d'autrui,

and except COMP if have.PRS.IND.3SG in fief.SG.OBL thing.FCI of=someone-else

lo senher deu aver balhat

ART.DEF.M.SG.SBJ sovereign.SG.SBJ must.PRS.IND.3SG have.INF rent.PTCP.M.SG.OBL

feuzater laic al senhor d'aquel

fiefholder.SG.OBL secular to=ART.DEF.M.SG.OBL lord.SG.OBL of=DEM.M.SG.OBL

feus dints un an e un mes, ... (XXI, 45r)

fief.SG.OBL within one.m year and one.m month

'and except that if he holds anything in fief from someone else, the sovereign must have provided a secular fiefholder to the lord of that fief within a year and a month,' 
One might wonder how the presence of $r e$ in conditional sentences should be accounted for. First of all, once the non-assertiveness of conditionals is agreed upon, an intuitive explanation of the presence of $r e$ in $s i$-clauses can be easily reached: by uttering a conditional antecedent, speakers do not commit themselves to conveying that they know things in the world are the way as the clause says. Therefore, applying an antecedent $p$ to a given consequence $q$ cannot be equated with adding an assertion $p$ to another assertion $q$.

Second, conditional sentences are not all alike, if seen against the background of epistemic links relating the propositional content of $s i$-clauses to the speaker's knowledge of the language-external reality. Three types of conditional constructions are distinguished: factual (the content of the protasis is presumed to be the case), counterfactual (the content of the protasis is presumed not to be the case) and hypothetical (Schwenter 1999: 11-12; see also Haspelmath 1997: 51), which is somewhere in between ${ }^{6}$. It is the last type that successfully captures the characteristics of the protases in the Costuma d'Agen. Hypotheses boil down to the meaning 'I don't know (whether $\mathrm{X}$ is really the case)', i.e. they are used for speculating about situations that are merely potential (Boissellier, Darbord \& Menjot 2012: 185-186). More concretely, in (7), the legislator does not take it for granted that the circumstances specified in the si-clause will ever take place. In a more philosophical vein, conditional sentences can be thought of as pairs of possible worlds and some consequences. Whether these consequences materialize or not may vary from one world to another (Giannakidou 1998: 131-134). Even if legal regulations are designed to find heuristics to situations known by experience, hindsight or received wisdom, their protases are manifestly non-factual.

The other two occurrences of re are found in temporal clauses introduced by 'before', thereby paralleling the use of rien in dependent clauses headed by ainz que in Old French. As noted by Hansen (2019), in Old French, the forms ainçois / ainz

With respect to this trichotomy, Schwenter's reasoning is based on two assumptions. First, hypotheses, whose task is to enable speakers to speculate about alternative situations or alternative future scenarios, must be based on uncertainties about their fulfillment. If the semantic component 'uncertainty' is absent, no alternative situation can be seriously considered by the interlocutors. Second, rather than being an instrument of logic and grammar, conditionals are seen as devices regulating the interaction among discourse participants. Schwenter (1999: 12-13) gives the following examples to substantiate his analysis (the parenthesized material is introduced to elucidate speaker's knowledge at the moment of utterance): If he said that (and I heard him), then he's a liar (factual), If he said that (I don't know if he did), then he's a liar (hypothetical), If he said that (I know he never would), than he would be a liar (counterfactual). 
had a temporal comparative source meaning. Old Occitan seems to have followed the same path.

\begin{tabular}{|c|}
\hline 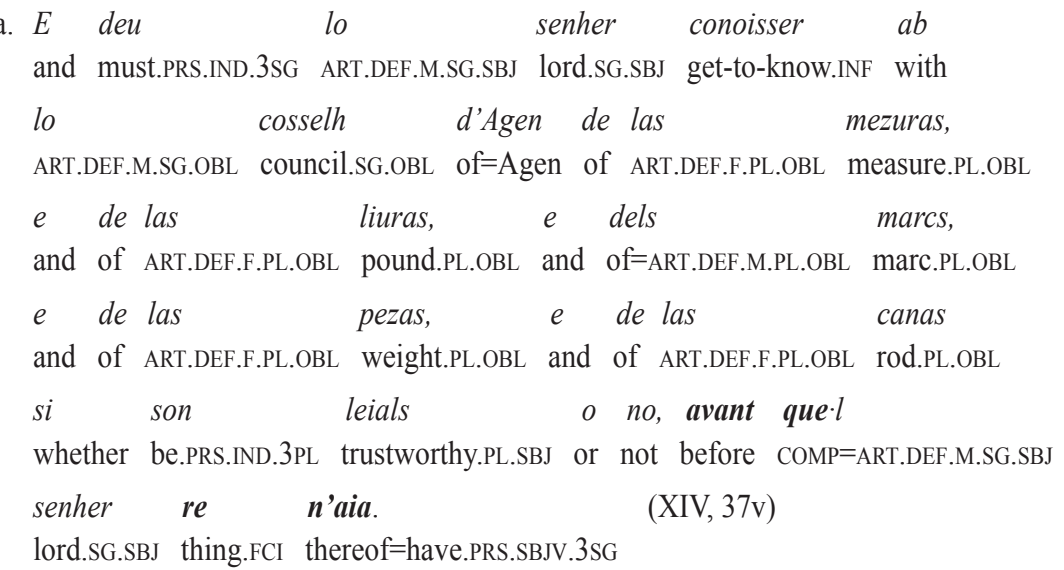 \\
\hline
\end{tabular}

'And the lord should judge with the council of Agen concerning measures and pounds and marks and weights and rods of length, concerning whether they are exact or not, before the lord gets anything.'

b. pero pagat a sa molher, si.n a, aquo but pay.PTCP.F.SG.SBJ to POSS.3.F.SG wife, if=thereof have.PRS.IND.3SG this.DEM.SG que.l deura per son dot o per als, REL $=$ CL-DAT.3SG owe.FUT.IND.3SG by POSS.3.M.SG dowry or by other-thing.PL.OBL $e$ sos deutes pagats primerament, $e$ avant and POSS.3.M.PL debt.PL.SBJ pay.PTCP.M.PL.SBJ first and before que $\cdot$ senher aia ni prenga re COMP=ART.DEF.SG.SBJ lord.SG.SBJ have.PRS.SBJV.3SG and-not take.PRS.SBJV.3SG thing.FCI de sa causas. (XV, 38r)

of POSS.3.F.PL thing.PL.OBL

'but his wife, if he has one, \{should be\} paid what he owes her as her dowry or as anything else, and his debts should be paid first, and before the lord collects or takes any of his property.'

The non-assertive character of these sequences is corroborated by the recurrent use of the subjunctive mood (aia, prenga). It is more challenging to show their nonassertiveness at the semantic level. To this aim, the concept of 'non-committal before', coined by Heinämäki (1974), is going to be evoked. Heinämäki discusses cases where the truth of the entire sentence can be accepted, while the truth of the before-clause need not be. James fled the country before anything happened implies the truth of 
'James fled the country', but fails to do so with respect to 'something happened'. The latter can be true or false, regardless of the truth of the sentence. Moreover, in some cases (which Heinämäki calls 'non-factual before'), the falsity of the before-clause is the prerequisite for the truth of the whole sentence. This is the case in James left before he said good bye to his children, which entails the falsity of James said good bye to his children. The use of $r e$ in 'avant que' clauses in the Costuma d'Agen will be associated with the 'non-committal' variant. In addition to being presented as merely potential, the truth of the seizure of someone's property $(8 b)$ is weakened by the fact that it hinges on the completion of the set of yet other conditions. In a nutshell, 'avant que' clauses in legal codices are strongly non-assertive. For this reason, they are thought to be fully in keeping with the indeterminacy of $r e$ 'anything'.

Thus, re outside negative concord is a free-choice item (FCI) as well' ${ }^{7}$. In what follows, this semantic profile is going to be characterized in more detail. FCIs are peculiar in that they quantify over a more extended referential domain than ordinary indefinites do (Colinet 2014: 110). They resemble NPIs in that they require all the items of the domain over which they quantify to be equally eligible referents (no matter which way / who / when, etc.). Likewise, in both of them, the choice of the referent is left up to the addressee. Moreover, free-choice semantics is incompatible with affirmative episodic sentences, which is how they are different from ordinary indefinites whose reference can be settled in such contexts. The label 'episodic' stands here for the reference to an event, whose semantic representation contains existential closure of the variable $e$ ( $e=$ event; see Giannakidou 1998: 75, taking advantage of Davidson's findings from the sixties). The incompatibility is supported by the perfective aspectual morphology of verbs denoting episodes. This event internal make-up is at odds with the variation requirement on FCIs, i.e. the fact that all the items over which FCIs quantify are equally eligible referents. Therefore, FCIs are expected to be found only in environments where this requirement is met. In Romance languages, variation is often morphologically encoded ${ }^{8}$. Moreover, FCIs exhibit quantificational

Taking as examples two French sentences Je ne veux pas en parler a qui que ce soit 'I don't want to talk to anybody about it' and Je ne veux pas en parler a n'importe qui 'I don't want to talk to anybody about it' (with a focal stress on any in anybody and the meaning 'just anybody' in the English version), Colinet (2014: 111-112) draws a distinction between NPIs and FCIs, respectively. According to her, the first of the sentences communicates that there is nobody the speaker wants to talk to. In the second the speaker merely says that he does not want to talk to someone at random. No special emphatic measures have been detected in the Costuma d'Agen, so, in what follows, re in both $\mathrm{NC}$ and non-NC contexts is considered a free-choice expression.

8 Ibero-Romance languages are known to have a special marking for FCIs, roughly corresponding to English -ever words (König 1988: 156-157). Cat. Pots venir qualsevol dia: sempre som a casa 'Drop 
unsteadiness: they may be equated either with existential quantifiers (for instance in imperatives) or with universal ones (see Boneh 2019: 11). Table 1 summarizes the properties of negative polarity items and free-choice expressions, thus accounting for how re behaves in negative concord and outside it.

\begin{tabular}{|l|c|c|c|}
\hline & $\begin{array}{c}\text { NPI } \\
\text { ([NEG] active) }\end{array}$ & indefinite & $\begin{array}{c}\text { free-choice } \\
\text { (equally eligible referents) }\end{array}$ \\
\hline re in negative concord & + & + & + \\
\hline re outside negative concord & - & + & + \\
\hline
\end{tabular}

TABLE 1. Semantic properties of re in the Costuma d'Agen

The variation requirement on free-choice expressions can be captured in terms of the attributive use of definite NPs. This observation can be traced back to Donnellan's (1966: 295-298) famous analysis of Smith's murderer is insane, whose meaning is ambiguous depending on how exactly the definite NP is interpreted. In the referential use, it refers to a particular individual who has the property of having murdered Smith and whose identity might be known at the moment of utterance. By contrast, the attributive use can be paraphrased as 'whoever murdered Smith'. In that case, no reference to any particular person is made: free-choice semantics is being equated with attributiveness.

Giannakidou (2012: 76-78) enumerates structural environments preferentially hosting FCIs. They are coincident with the contexts in which re is found in the Costuma d'Agen, both in $\mathrm{NC}$ structures and outside them'. The indefinite value of this expression transits via free-choice contexts, among which negative sentences play an essential role. Rather than having become indefinite pronouns straightaway, erstwhile generic nouns become entrenched first as FCIs in a range of syntactically constrained

by any day you want. We're always home'; Sp. Quienquiera que sea el ganador lo sera por pocos votos 'Whoever wins will be elected by a narrow majority'; Port. Quem quer que tente subverter a nossa liberdade não merece ser primeiro-ministro 'Whoever tries to tamper with our freedom doesn't deserve to be the prime minister'. The elements vol, quiera, quer are grammaticalized want-verbs. If followed by the restrictive relative pronoun, they impose the subjunctive mood on the verb in the subordinate clause.

9 The list contains the following contexts: 1. restrictions of universal quantifiers (e.g. everyone who ...); 2. clausal comparatives (more / less X than + clause); 3. subjunctives (e.g. insist that ...); 4. modal verbs; 5. implicit modals (e.g. Anyone is welcome); 6. imperatives; 7. future; 8. habitual statements; 9. too-clauses (too X to + clause; 'purposive complement of an excessive comparative' see Haspelmath 1997: 35); 10. without-clauses; 11. before-clauses; 12. direct objects of negative predicates; 13. generic statements. 
environments. The grammaticalization of $r e$ in $13^{\text {th }}$ century Occitan reached the point where the original nominal morphosyntax of RES, REI had been definitively lost: re does not inflect for number and fails to occur with determiners or modifiers. Its subjecthood turns out to have eroded as well: the codex contains no attestations of $r e$ being used as an indefinite subject.

As thirty occurrences retrieved from a single text can hardly substantiate any claim on how Latin common nouns were turning into Occitan indefinites, a subsidiary survey was carried out. Its aim is to see whether the results arrived at in the Costuma d'Agen are the same as in the texts originating from a neighboring linguistic zone. The descendant of Lat. REM is the only lexeme taken into account.

The analysis has been underpinned by the data retrieved from Th. Field's corpus of Old Gascon (LCOG - The Linguistic corpus of Old Gascon; milldev.umbc.edu/ gascon) consisting of texts written prior to $1500^{10}$. The query included eight texts (see their list alongside references) from the $13^{\text {th }}$ and the first quarter of the $14^{\text {th }}$ century. In the first stage, a manual search was conducted to retrieve all the negative clauses. In the next step, clauses without negative concord were rejected. Likewise, negative clauses with NPIs other than the cognates of Agen's re were left out of analysis. In the remaining examples, expressions originating from Lat. REM were annotated for their graphic form. Once all the spellings had been identified, an automatic query was activated to retrieve environments other than the negative clauses. In three of the documents, no expression whatsoever was likely to be put in correspondence with Agen's re. In the remaining ones, 31 cognates of $r e$ were found in two contexts: conditional protases and negative concord.

For the aims pursued in this part, an important local property involves a different realization of $r$-initial words of Latin origin (e.g. Occ. recebre - Gasc. arrecéber): the predominant spelling of the Central Occitan re in Gascon is arren. Apart from arren, other forms, both vowel-initial and $r$-initial, are documented in object function (see Table 2) in the corpus. For example, in the sentence below, two occurrences of arren displaying different values are juxtaposed.

$\begin{array}{lllllll}\text { (9) que } & \text { nulhs } & \text { hom } & \text { estrah } & \text { noy } & \text { bena } & \text { draps } \\ \text { COMP } & \text { no.DET.M.SG } & \text { man.M.SG } & \text { foreign.M.SG } & \text { NEG=there } & \text { sell.PRS.SBJV.3SG fabric.M.SG }\end{array}$

10 Although the variety spoken in Agen in the Middle Ages is considered to be part of Central Occitan, Agen itself is localized at the western ridges of this linguistic domain. Further to the west of the Garonne river, a different geo-linguistic area, Gascon, is localized (Rohlfs 1970 [1935]). 
a talh, ni $i$ tengua obrador, mays solament atant

in cut, and-not there have.PRS.SBJV.3SG worker.M.SG but only as-long-as con la feira dura, viii. dias deuante viii. dias when ART.DEF.F.SG fair.F.SG last.PRS.IND.3SG eight day.M.PL before and eight day.M.PL derrer; si arren no $y$ ben, no $y$ deu auer thereafter if thing.FCI NEG there sell.PRS.IND.3SG NEG there must.PRS.IND.3SG have.INF arren lo senhor. thing.NPI ART.DEF.M.SG lord.M.SG 'that no foreigner is allowed to sell fabric in cut pieces or hire workers except for the duration of the fair including eight days before and eight days afterwards; if nothing is sold, the lord receives nothing' (CoutSGaudensM 26, 7-11)

\begin{tabular}{|l|c|c|c|c|c|c|}
\hline & date & words & form & NPI & FCI cond. & occurrences \\
\hline CoutSGaudensM & 1202 & 4378 & arren & 4 & 6 & $9(1$ instance=NPI \& FCI $)$ \\
\hline CartSCrD & $1244-72$ & 14982 & arre, res, re & 7 & 2 & 8 (1 instance=NPI \& FCI $)$ \\
\hline CoutCastelnauM & 1309 & 3669 & arres, are, res & 1 & 3 & 4 \\
\hline CoutMunC & 1292 & 919 & re & 1 & & 1 \\
\hline ChartValcabrA & 1318 & 3838 & arren, ren & 6 & 3 & 9 \\
\hline
\end{tabular}

TABLE 2. Occurences and functions of Gascon expressions originating from REM (source: LCOG)

As can be inferred from the above table, Gascon offers cases which depart radically from their Agen's counterparts. The first occurrence of arren in the above example is special in that it materializes, at the same time, free-choice indefiniteness in the scope of the si conditional and negative polarity in NC. Such cumulative uses are absent in the Costuma d'Agen. Moreover, unlike in Lot-et-Garonne's text, the Gascon $<$ REM occurs as an agreement controller (Et se nulha res ne defalhe ... '... and if nothing [lit. no thing] goes wrong'; CartSCrD.CLXX 173, 21) in subject function. The latter property is considered here to be reminiscent of the erstwhile status of res, i.e. a fully-fledged noun. If this analysis is probative, then it comes out that Gascon expressions descending from REM were less advanced on the grammaticalization scale. In the $13^{\text {th }}$ century, they keep more original features of their Latin etymon than their Central Occitan counterparts documented in the Costuma d'Agen. 


\section{FREE-CHOICE SEMANTICS AND TEXT GENRE CHARACTERISTICS}

The hypothesis presented in the preceding section is further corroborated by the diaphasic status of the Costuma d'Agen. Therefore, apart from conditions defined on a strictly grammatical basis, in the evolutionary drift from generic nouns towards FCIs and, subsequently, to indefinites, speaker-orientated factors may have been consequential as well. One of these factors involves the discourse architecture of particular kinds of texts. In the case under discussion, regular linkages are assumed to exist between the construal of legal regulations and the quantificational force of former generic nouns (and NPs in general). No wonder that REM, a fully-fledged noun in Latin, which may have displayed clear-cut referential links with extra-linguistic reality (see: quod ipsa res declaravit, Cic., Verr. II.4, 63 'as shown by the course of events itself'), grammaticalizes in certain kinds of texts more easily than in others.

The very nature of juridical regulations consists in pairing premises (potential states of affairs) with some results, construed as universal deontic judgements (Stage 2002: 56). Another trichotomy worked out by Schwenter (1999) proves helpful in accounting for why conditional constructions are ubiquitous in legal texts. They vary according to what the speaker is doing in the apodosis ${ }^{11}$. In content conditionals a simple assertion about the external world is produced; in such cases, the protasis specifies the state of affairs enabling the speaker to produce the assertion. In speech-act conditionals, some behavioral stance is taken towards the situation communicated in the apodosis. In the Costuma d'Agen, they have an essentially prospective orientation: usually a particular state of affairs is opted for, which is how deontic modality materializes (Akehurst 2010, Introduction XX). Obligations, duties, or prohibitions aim to coerce addressees into a particular conduct, and, in doing so, they prevent imminent misbehaviors or state how, once committed, they are to be sanctioned. The protasis shows, then, why or under what circumstances a given speech act is 'felicitous'. Finally, epistemic conditionals appear if an inference, whose symptoms are given in the protasis, is drawn by the speaker (Schwenter 1999: 13-15). This type is virtually absent in the Costuma d'Agen.

Both premises (protases) and results (apodoses) are presented as likely to take place at no specific moment or time interval, an inherent property of legal regulations,

11 This tripartition is designed to depict the relationship between the propositions $\mathrm{P}$ (protasis) and Q (apodosis). Moreover, certain semantic and syntactic characteristics are recurrent in each of the types. Time reference in content conditionals is obligatorily earlier than the reference of apodosis' finite verb form. In epistemic conditionals, the reverse is true - time reference of the verb in the protasis ("at present") is posterior to time reference of the verb in the apodosis (before "at present"). In speech-act conditionals, aside from the imperative, other non-assertive forms (mainly questions displaying various undertones) can be found in the apodosis. 
which are, in addition, designed with no reference to particular individuals or objects (Rusiecki 1991: 365-366). These characteristics fit in well with the free-choice status of re. Conversely, more subjective narratives forming dramatic plots are permeated with specifically used nouns. Such uses are not in keeping with the unclear referential status of re.

Rather than using traditional variationist parameters evoked in sociolinguistics (degrees of formality, divergent communicative functions and circumstances in which an utterance is produced; see Ernst 2015: 72-76), the diaphasic dimension is going to be defined here with the aid of slightly modified criteria. Since the pioneering work by Koch and Oesterreicher (2001), text genres have tended to be approached in terms of the proximity vs. distance poles dichotomy. These poles represent opposite end points of a cline with various text characteristics interspersed in between. This division roughly corresponds to orality as opposed to written communication (Koch $\&$ Oesterreicher 2011) ${ }^{12}$. Unlike traditional parameters, the poles singled out by Koch and Oesterreicher are helpful for the characterization of text genres, which represent a certain discourse tradition and can be classified according to the degree to which they comply with different parameters on the scale (Kabatek 2018).

\begin{tabular}{|c|c|c|}
\hline & Proximity & Distance \\
\hline 1 & private communication & public communication \\
\hline 2 & addressee known beforehand & unknown addressee \\
\hline 3 & high incidence of emotions & minimal emotional load \\
\hline 4 & $\begin{array}{l}\text { reference to the situation of utterance and its } \\
\text { participants }\end{array}$ & $\begin{array}{l}\text { no reference to the situation of utterance or to its } \\
\text { participants }\end{array}$ \\
\hline 5 & sameness of space and time & separation in time and space \\
\hline 6 & strong communicative cooperation & minimal communicative cooperation \\
\hline 7 & dialogue & monologue \\
\hline 8 & spontaneous communicative acts & planned communicative acts \\
\hline 9 & freely chosen topic of conversation & fixed topic \\
\hline
\end{tabular}

TABLE 3. Parameters of the proximity vs. distance poles in Koch and Oesterreicher (2001)

12 One of the anonymous reviewers, to whom I am indebted for this remark, notes that Koch and Oesterreicher's approach is much older than their work referenced in the present paper. Their original paper dates back to 1985 ("Sprache der Nähe - Sprache der Distanz. Mündlichkeit und Schriftlichkeit im Spannungsfeld von Sprachtheorie und Sprachgeschichte”, Romanistisches Jahrbuch 36: 15-43), which I have not been able to get hold of. Importantly, the reviewer insists on the fact that, rather than being dependent on the medium of communication, the dichotomy introduced by these two scholars corresponds to conceptual orality and conceptual writtenness. Moreover, the same reviewer notes that in Kabatek's analysis (2018: 207; based on an earlier version in German from 2011), text genres and discourse traditions stand in part-whole relation to each other. 
Except for geographical immobility (see example (10) below), alluded to by points 2 and 5 in Table 3, the Costuma d'Agen fulfils all the requirements of a distance pole text, as legal texts usually do. It is of public interest, extending over whoever happens to have their abode in Agen or its whereabouts.

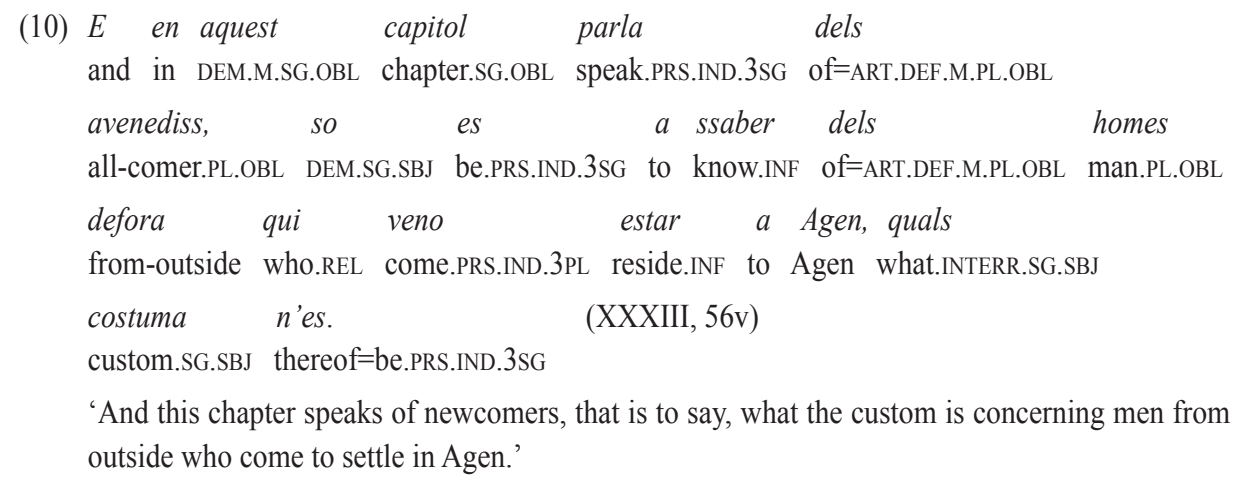

\section{DISCUSSION}

The case considered in the preceding sections shows that free-choice contexts represent an intermediate, syntactically constrained stage in the development of some common nouns towards their new pronominal status. Yet, it is noteworthy that not all of these nouns evolve at the same pace, so that the outcomes of their evolutions are not all alike, but call for some more subtle refinements. As far as Romance indefiniteness is concerned, animacy and humanness turn out to have been two prominent paceregulating factors. Their relevance becomes clear as soon as the Occitan re is contrasted with the terms derived from Lat. HOMO, -INIS 'human being, man'. Even if some of their uses resemble re in that they appear in the same syntactic environments (mostly conditional protases), there are several important differences. First of all, unlike re, hom $(e)$ persists as a plain noun in Old Occitan and numerous other Romance languages. During intermediate stages, both the meaning and grammatical characteristics of a given unit often reflect a dominant earlier value (Hopper 1991: 28). Indeed, Occitan hom (e) keeps some of the morphosyntactic features of the Latin noun intact: it inflects for number, can be modified, can receive determiners (11a) and occurs in subject function (11b). By contrast, as far as the object function is concerned, a different lexeme turns out to be preferred (see the discussion of (14) below). 
(11) a. Si entre alcus homes o femnas de la

if between any.M.PL.OBL man.PL.OBL or woman.PL.OBL of ART.DEF.M.PL.OBL

ciutat borcs d'Agen a

town.PL.OBL or of $=$ ART.DEF.M.PL.OBL suburb.PL.OBL of $=$ Agen have.EXIST.PRS.IND.3SG

questio de deutes o de covents, aquel qui

matter.F.SG of debt.PL.OBL or of contract.PL.OBL DEM.M.SG.SBJ who.REL

volra demandar lo deute o.l

want.FUT.IND.3SG claim.INF ART.DEF.M.SG.OBL debt.SG.OBL or=ART.DEF.M.SG.OBL

covent leu l'autre enquer[r]e

contract.SG.OBL must.PRS.IND.3SG ART.DEF.M.SG.OBL=other.SG.OBL proceed-the-case.INF

ab testimoni de la meissa ciutat o

with witness.PL.OBL of ART.DEF.F.SG.OBL same.SG.OBL town.SG.OBL or

dels borcs d'Agen (V, 25r)

of $=$ ART.DEF.M.PL.OBL suburb.PL.OBL of $=$ Agen

'If there is a dispute about debts or contracts between men or women of the town of Agen or its suburbs, the person wishing to lodge the complaint over debt or contract must seek a settlement from the other in the presence of a witness from the said town or suburbs of Agen'.

b. E tughs home d'Agen son $e$ and all.DET.PL.M.SBJ ART.DEF.PL.M.SBJ man.PL.SBJ of=Agen be.PRS.IND.3PL and estre devo franc a Lafodz ab totas

be.INF must.PRS.IND.3PL exempt.PL.SBJ at Lafox with all.DET.PL.F.OBL lors causas, e per tota ta terra POSS.3.F.PL thing.PL.OBL and across all.DET.SG.F.OBL ART.DEF.PL.F.OBL land.SG.OBL de la senhoria de Bouvila, de tots peatges, of ART.DEF.SG.F.OBL county.SG.OBL of Beauville from all.DET.PL.M.OBL payment.PL.OBL e de totas leidas, (XXVIII, 51v-52r) and from all.DET.PL.F.OBL charge.PL.OBL

'And all the men of Agen, throughout the lands of the lordship of Beauville, are and must be exempt at Lafox with all their properties from all tolls and payments,'

Second, in Old Occitan hom(e) is also a stressed pronominal $n$-word ('nobody') $)^{13}$. In line with what has been said in section 3 , a clausal negative marker is a prerequisite for this usage. Taken as an $n$-word, hom(e) is extensively documented in the Costuma

13 This use has been recorded by Jensen (1986: 165), who illustrates it with: meyllor vassal non vid ainz hom 'nobody has ever seen a better vassal' and no deuria esser hom temeros de suffrir mort 'no one ought to be frightened when suffering death'. 
d'Agen. Unlike re, it tends to occur as a subject, both preverbal and postverbal (see examples (12a-b) and (12c)). Still, rather than using hom(e) as a plain NPI, preference is frequently given to the preverbal negus hom 'no man' sequence (12c). Alternatively, the negus ( $<$ Lat. nec unus) preverbal pronoun, appears on its own as an $n$-word in $\mathrm{NC}$ with reference to persons (12d).

(12)

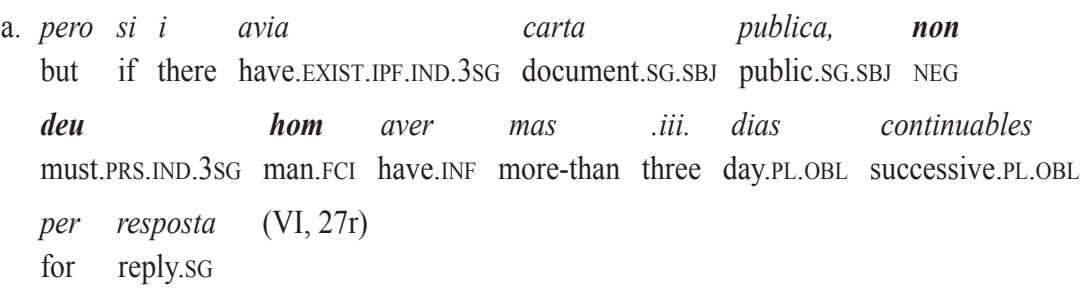

'but should a public document exist, nobody must be allotted more than three days for an answer / no more than three days should be allotted for an answer, (author's translation)

b. Pero en questio de raubaria ni de crim no

but in matter.SG.OBL of robbery.SG.OBL and-not of crime.SG.OBL NEG

deu hom aver dia (VI, 28r)

must.PRS.IND.3SG man.FCI have.INF day.SG.OBL

'But in cases of robbery or crime nobody must be allotted (another) date / no other date should be allotted,' (author's translation)

c. No es causa razonabla que negus hom

NEG be.PRS.IND.3sG thing.SG.SBJ reasonable.F.SG COMP no.DET.M.SG.SBJ man.SG.SBJ

s'enclava de noghs en maio d'autrui

CL.REFL.3SG=shut.PRS.IND.3SG at night in house.SG.OBL of =other

'It is not reasonable for any man to stay closed in someone else's house at night'

d. negus no pot proar contra home d'Agen

nobody.SG.SBJ NEG can.PRS.IND.3SG testify.INF against man.SG.OBL of=Agen

si testimoni d'Agen no $i$ avia (VII, 28r)

if witness.PL.SBJ of=Agen NEG there have.EXIST.IPF.IND.3SG

'no one is allowed to give evidence against a man from Agen unless there are witnesses from Agen' (author's translation)

Third, apart from hom(e), Old Occitan indefiniteness makes use of autrui, another human-denoting lexeme. It is documented in free-choice contexts, including as an NPI in negative concord. Unlike hom(e), this lexical element specializes in 
encoding the semantic role of possessor. No comparable distinctions are found in the inanimate domain, where $r e$ is an all-encompassing form. The importance of this particular development has to do with Heine and Kuteva's list of putative sources for A-Possessives (genetivus possessoris) ${ }^{14}$. Whereas Latin res failed to evolve in this direction, this meaning was felt worth encoding with respect to human beings and things they own. This evolutionary inequality is due to the semantics of possession, which is not the same in human and non-human domains. Individuals can possess objects (goods, values) in a manner that is radically different from how one object is related to another. In the case of inanimate objects, the most common relation is part - whole or thing - its characteristic, but not: owner - owned. No wonder that A-Possession fails to be encoded with inanimates.

The origin of autrui can be traced back to Latin alter '(the) other (out of two)', with an analogical ending replicating cui, sui, etc. In both $\mathrm{NC}$ and non-NC contexts, its meaning can be equated with 'other people's' or 'someone else's'. Autrui is also indicative of the non-universal character of the evolution from common nouns into indefinite pronouns. Compared to re and $\operatorname{hom}(e)$, it appears to have followed the reverse path: the Latin adjective or fully-fledged pronoun with a range of indefinite uses had two different outcomes, one of which was a common noun (see example (14) below). In the Costuma d'Agen, it also exhibits a particular linear patterning: if used as an A-Possessive pronoun, autrui invariably precedes the noun denoting the thing possessed (13a). This order can switch to possessum-de-autrui (13b).

(13) a. E si alcus hom o femna metia foc and if any.M.SG.SBJ man.SG.SBJ or woman.SG.SBJ put.IPF.IND.3SG fire.SG.OBL

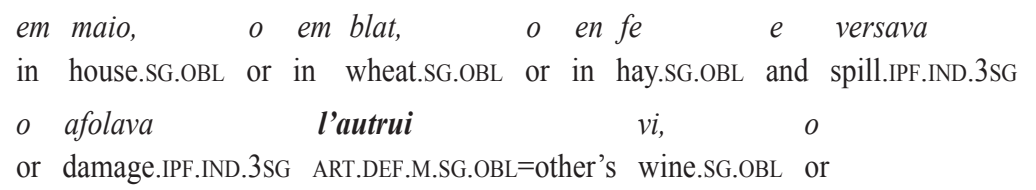

l'autrui oli, o l'autrui mel, ART.DEF.M.SG.OBL=other's oil.SG.OBL or ART.DEF.M.SG.OBL=other's honey.SG.OBL

$\begin{array}{lllll}\text { o } \begin{array}{l}\text { aucizia } \\ \text { or }\end{array} \text { kill.IPF.IND.3SG } & \text { ART.DEF.M.SG.OBL=other's } & \text { horse.SG.OBL } & \text { or } & \text { ART.DEF.M.SG.OBL=other's } \\ \text { bestia, } & o & \text { talava } & \text { l'autrui } & \text { vinha, } \\ \text { animal.SG.OBL } & \text { or } & \text { cut.IPF.IND.3SG } & \text { ART.DEF.M.SG.OBL=other's } & \text { vineyard }\end{array}$

$14 \quad$ Heine \& Kuteva (2002: 24) give the following 'approximate gloss and descriptive note' of A-POSSESSIVES: “ 'of'; marker of attributive (nominal) possession, genitive case, associative, connective, nominal possessive." 
$o \cdot l_{S} \quad$ autrui arbres, o l'autrui blat

or $=$ ART.DEF.M.PL.OBL other's tree.PL.OBL or ART.DEF.M.SG.OBL=other's wheat.SG.OBL

passaria pena a esgart del

undergo.PRS.COND.3SG punishment.SG.OBL with-respect-to of=ART.DEF.M.SH.OBL

senhor $e$ del cosselh d'Agen, $(\mathrm{XV}, 38 \mathrm{v})$

lord.SG.OBL and of=ART.DEF.M.SG.OBL council.SG.OBL of $=$ Agen

'And if some man or woman set fire to a house, or to wheat or hay, or spilled or spoiled someone else's wine or oil or honey, or killed someone's horse or other animal, or cut down someone's vines or trees or wheat, they would be given a punishment at the ruling of the lord and the council of Agen,'

b. Ni eissament es de razo que negus

and-not equally be.PRS.IND.3SG of reason.SG.OBL COMP nobody.SG.SBJ

intre de dias en la maio

enter.PRS.SBJV.3SG at day.PL.OBL in ART.DEF.F.SG.OBL house.SG.OBL

d'autrui

$(\mathrm{XX}, 43 \mathrm{v})$

of $=$ someone.else.SG.OBL

'Likewise, it is not reasonable that anybody should enter someone else's house by day' (author's translation)

Apart from being specialized in encoding possession, autrui is also found in non-NC and non-possessive free-choice contexts in the object function, where its value becomes indistinguishable from that of $\operatorname{hom}(e)$. $\operatorname{Hom}(e)$ is outnumbered by far by autrui in this particular syntactic function.

(14) tractem cum cadaus se garde cum treat.PRS.SBJV.1PL how every.one.M.SG.SBJ CL-REFL.3SG beware.SBJV.3SG how metra autrui em plaghs si a put.FUT.IND.3SG other.SG.OBL in lawsuit.SG.OBL if have.PRS.IND.3SG razo ni dreghs per quell deia metre reason.SG.OBL and-not law.SG.OBL by REL=CL-ACC.3.M.SG must.PRS.SBJV.3sG put.INF em plaghs, que no.l tribalhe en va ni in lawsuit.SG.OBL COMP NEG=CL.ACC.3.M.SG worry.PRS.SBJv.3SG in vain and-not no-degudament. Quar mants homes comenso calonjar $e$ not-duly because numerous.M.PL.SBJ man.PL.SBJ start.PRS.IND.3PL offend.INF and demandar mantas causas per barat, per tribalhar sue.INF numerous.F.PL.OBL case.PL.OBL by idleness so-as-to worry.INF 
$\begin{array}{llllll}\text { autrui } & \text { contra } & \text { cui } & \text { no } & \text { an } & \text { drechurera actio, (XII, 33r-33v) } \\ \text { other.SG.OBL against } & \text { REL NEG have.PRS.IND.3PL righteous deed }\end{array}$

'let us deal with how each person should be careful how they sue others in lawsuits, if they have a good reason or a law under which they should sue the other person, so that they do not harass them in vain or improperly. Many people begin to make challenges and to lodge many complaints ill-advisedly, in order to harass persons against whom they have no rightful claim,' (author's translation)

\section{CONCLUSION}

In the light of what has been said above, the following observations can be made about the evolutionary path leading from generic common nouns to indefinite pronouns in Old Occitan. Rather than moving freely between the two types of polarity, re is distributed over both of them simultaneously. Irrespective of the polar value, its syntactic freedom in the Costuma d'Agen is constrained: the object position is the only documented one. In NC contexts, it never plays the role of a negative quantifier. This corroborates once more the observations of those scholars who advance that Old Romance NC used to be strict (Gianollo 2018: 22-23). The syntactic freedom of re outside NC contexts is rigorously constrained likewise. In the Costuma d'Agen, re occurs in either conditional protases or before-clauses. All of these usages can be conveniently subsumed under just one broad category: free-choice quantification. Consequently, its diachronic development may be seen as unidirectional. Moreover, in Agen's text $r$ fails to show up in positive episodic assertions, as the plain indefinite could have done. This bears witness to an indirect character of the reanalysis under discussion, involving numerous intermediate, non-overlapping stages.

Finally, the comparison of $r e$ with human-denoting emergent indefinites yields some interesting results. It is indicative of the differences in how the evolution unfolds depending on the semantic domain to which the original lexical units belong. Nouns denoting non-animates display twofold, yet intertwined, developments. As demonstrated above, $r e$ is found in either NC or non-NC contexts, being a freechoice item in both of them. By contrast, the evolutionary status of human-denoting common nouns in the Costuma d'Agen is more intricate. First of all, in addition to drifting towards indefinite pronouns, some of them preserve their original fullyfledged nominal character (inflectability, ability to be determined and modified, subjecthood). Second, they become a playground for some more subtle semantic and lexical distinctions, as evidenced by the complementary distribution of home and autrui in the Costuma d'Agen. 


\section{ACKNOWLEDGEMENTS}

The research whose results are exposed in the present paper has been funded by National Science Centre, Poland (Narodowe Centrum Nauki, ncn.gov.pl) under the agreement UMO-2016/22/M/HS2/00168 (funding initiative Harmonia8). I wish to thank the editors of this volume and two anonymous reviewers for their insightful and helpful comments. The remaining drawbacks are mine.

\section{UNCOMMON ABBREVIATIONS IN GLOSSES}

EXIST - existential (in constructions such as Eng. There are, Fr. Il y $a$, Pt. há)

IPF - imperfect (Leipzig's IPFV)

$\mathrm{CL}$ - clitic pronoun

NPI - negative polarity item

FCI - free-choice item

PRF - perfect (Leipzig's PFV)

INTERR - interrogative

\section{REFERENCES}

Akehurst, R. (ed.) (2010): The "Costuma d'Agen": a thirteenth-century customary compilation in Old Occitan. Transcribed from the "Livre Juratoire". Turnhout: Brepols. http://doi.org/10.1484/M.PAIEO-EB.5.112502

BATLLORI, M. (2019): "Tipologia de la concordança negativa i caracterizació dels mots negatius en català i en espanyol medievals", paper read at the XXIX International Congress of Romance Linguistics and Philology. Section 4: Syntax. University of Copenhagen. København (July 2019).

BEC, P. (1987): Anthologie de la prose occitane du moyen âge, vol. 2. Valdariás: Vent Terral.

Boissellier, S., DARbord, B. \& Menjot, D. (2012): Langues médiévales ibériques: domaines espagnol et portugais (with the assistance of G. Martin, J.-P. Molénat y P. Teyssier). Turnhout: Brepols. 
Boneh, N. (2019): "Dispositions and characterizing sentences", Glossa: A Journal of General Linguistics 4 (1), 130. http://doi.org/10.5334/gjgl.540

CAPIN, D. (2014): "Chaînes de référence dans les textes médiévaux non-narratifs: les Year Books ou l'élaboration d'une écriture juridique”, Langages 195 (3), pp. 61-78.

Colinet, M. (2014): "A pragmatic analysis of the differences between NPIs and FCIs", in K. Lahousse \& S. Marzo (eds.): Romance languages and linguistic theory 2012. Selected papers from 'Going Romance', Leuven 2012. Amsterdam/ Philadelphia: John Benjamins, pp. 109-122. https://doi.org/10.1075/rllt.6.05col Denić, M., Chemla, E. \& Tieu, L. (2018): "Intervention effects in NPI licensing: A quantitative assessment of the scalar implicature explanation", Glossa: A Journal of General Linguistics 3 (1), 49. http://doi.org/10.5334/gjgl.388

Donnellan, K. (1966): "Reference and definite descriptions", Philosophical Review 75, pp. 281-304.

DRYER, M. S. (1988): "Universals of negative position", in M. Hammond, E. Moravcsik \& J. Wirth (eds.): Studies in syntactic typology. Amsterdam/Philadelphia: John Benjamins, pp. 93-124. https://doi.org/10.1075/tsl.17.10dry

ERNST, G. (2015): "La diachronie dans la linguistique variationnelle du français", in C. Polzin-Haumann \& W. Schweickard (eds.): Manuel de linguistique française. Berlin: De Gruyter, pp. 72-107. https://doi.org/10.1515/9783110302219-005

Giannakidou, A. (1998): Polarity sensitivity as (non) veridical dependency. Amsterdam/ Philadelphia: John Benjamins. https://doi.org/10.1075/la.23

Gianollo, Ch. (2018): Indefinites between Latin and Romance. Oxford: Oxford University Press. https://doi.org/10.1093/oso/9780198812661.001.0001

HANSEN, M.-B. Mosegaard (2019): "Semantic / pragmatic cyclicity in the evolution of pragmatic markers: the case of French ainçois/ ainz and plus tôt/ plutôt", paper read at the 24th International Conference on Historical Linguistics, Australian National University, Canberra (July 2019).

Haspelmath, M. (1997): Indefinite pronouns. Oxford: Oxford University Press. https:// doi.org/10.1093/oso/9780198235606.001.0001

Heine, B. \& Kuteva, T. (2002): World lexicon of grammaticalization. Cambridge: Cambridge University Press.

HeInämäKI, O. (1974): Semantics of English temporal connectives. PhD thesis. Austin: University of Texas. 
Hopper, P. J. (1991): “On some principles of grammaticization”, in E. Closs Traugott \& B. Heine (eds.): Approaches to grammaticalization. Vol. I. Theoretical and methodological issues. Amsterdam/Philadelphia: John Benjamins, pp. 17-36. https://doi.org/10.1075/tsl.19.1

HoRN, L.R. (2016): "Licensing NPIs: some negative (and positive) results", in P. Larrivée \& Ch. Lee (eds.): Negation and polarity: experimental perspectives. Cham: Springer, pp. 281-305. https://doi.org/10.1007/978-3-319-17464-8_12

JEnsen, F. (1986): The syntax of Medieval Occitan. Tübingen: Max Niemeyer Verlag. KABATEK, J. (2018): Lingüística coseriana, lingüística histórica, tradiciones discursivas. Madrid/ Frankfurt am Main. Iberoamericana/Vervuert.

Koch, P. \& Oesterreicher, W. (2001): “Langage parlé et langage écrit”, in G. Holtus, M. Metzeltin \& Ch. Schmitt (eds.): Lexikon der romanistischen Linguistik(LRL). Band I/2. Tübingen: Max Niemeyer Verlag, pp. 584-627.

Koch, P. \& Oesterreicher, W. (2011): “Die einzelsprachlichen Merkmale des gesprochenen Französisch, Italienisch und Spanisch in diachronischer und synchronischer Perspektive" in: P. Koch \& W. Oesterreicher (eds.): Gesprochene Sache in der Romania: Franzözisch, Italienisch, Spanisch. Berlin/New York: De Gruyter, pp. 135-272. http://dx.doi.org/10.1515/9783110252620.135

KÖNIG, E. (1988): “Concessive connectives and concessive sentences: cross-linguistic regularities and pragmatic principles", in J. Hawkins (ed.): Explaining language universals. Oxford: Blackwell, pp. 145-166.

LARrivÉE, P. (2017): "Negation and polarity", in A. Dufter \& E. Stark (eds.): Manual of Romance morphosyntax and syntax. Berlin/Boston: De Gruyter, pp. 449-471. https://doi.org/10.1515/9783110377088-012

LeOnetTI, M. (2012): "Indefiniteness and specificity", in J. I. Hualde, A. Olarrea \& E. O'Rourke (eds.): The Handbook of Hispanic Linguistics. West Sussex UK: Wiley, pp. 285-305. https://doi.org/10.1002/9781118228098.ch15

Maiden, M. \& Robustelli, C. (2000): A reference grammar of Modern Italian. London-New York: Routledge. https://doi.org/10.4324/9780203783504

Martin, R. (1966): Le mot 'rien' et ses concurrents en français (du XIVe siècle a l'époque contemporaine). Paris: Klincksieck.

Martins, A. M. (2014): "Syntactic change in Portuguese and Spanish: divergent and parallel patterns of linguistic splitting”, in P. Amaral \& A. M. Carvalho (eds.): Portuguese-Spanish interfaces: diachrony, synchrony and contact. Amsterdam/ Philadelphia: John Benjamins, pp. 35-64. https://doi.org/10.1075/ihll.1.04mar 
Poletto, C. (2016): "Negation", in A. Ledgeway \& M. Maiden (eds.): The Oxford Guide to the Romance languages. Oxford: Oxford University Press, pp. 833-846. https://doi.org/10.1093/acprof:oso/9780199677108.003.0051

Przepiórkowski, A. \& Kupść, A. (1997): Negative concord in Polish. Technical report 828. Warszawa: Institute of Computer Science-Polish Academy of Sciences. http://nlp.ipipan.waw.pl/ adamp/Papers/1997-828/index.html

RohlFs, G. (1970 [1935]): Le gascon: études de philologie pyrénéenne (2nd edn.). Tübingen/Pau: Niemeyer/ Marrimpouey Jeune.

RUSIECKI, J. (1991): “Generic sentences, classes of predicate and definite generic noun phrases", in M. Grochowski \& D. Weiss (eds.): Words are physicians for an ailing mind. München: Otto Sagner, pp. 363-370.

SCHøSLER, L. \& VölKeR, H. (2014): "Intralinguistic and extralinguistic variation factors in Old French negation with ne-Ø, ne-mie, ne-pas and ne-point across different text types", Journal of French Language Studies 24 (1), pp. 127-153. http://dx.doi.org/10.1017/S0959269513000379

SCHWENTER, S. (1999): Pragmatics of conditional marking: implicature, scalarity and exclusivity. New York/ London: Garland Press.

Schwenter, S. (2014): "Two kinds of differential object marking in Portuguese and Spanish", in P. Amaral \& A. M. Carvalho (eds.): Portuguese-Spanish interfaces: diachrony, synchrony, and contact. Amsterdam/ Philadelphia: John Benjamins, pp. 237-260. https://doi.org/10.1075/ihll.1.12sch

StaGe, L. (2002): "Les modalités épistémique et déontique dans les énoncés au futur (simple et composé)", Revue Romane 37 (1), pp. 44-66.

VendRYÈs, J. (1950): "Sur la négation abusive", Bulletin de la Société de Linguistique de Paris 46 (1), pp. 1-18.

Zeijlstra, H. H. (2004): Sentential negation and negative concord. $\mathrm{PhD}$ thesis. Amsterdam: University of Amsterdam.

ZeIJlstra, H. H. (2007): "Negation in natural language: on the form and meaning of negative elements", Language and Linguistic Compass 1 (5) pp. 498-518. https:// doi.org/10.1111/j.1749-818X.2007.00027.x 


\section{ONLINE SOURCES}

DOM en ligne. Dictionnaire de l'Occitan Médiéva http://www.dom-en-ligne.de/index. $\mathrm{html}$. Bayerische Akademie der Wissenschaften-Union der Deutschen Akademien der Wissenschaften.

Field, Thomas. LCOG - the Linguistic Corpus of Old Gascon. University of Maryland. Baltimore. http://mllidev.umbc.edu/gascon/

Texts from the LCOG:

1. Une Chronique béarnaise inédite du quatorzième siècle. ChronBearnC, early 14th c. 746 words. Bearn (south) http://mllidev.umbc.edu/gascon/English/ documents/ChronBearnC.html

2. Abbaye de la Case-Dieu. DocCaseDieuG, 1274-1280. 907 words. Montesquiou (center), Vic (south), Saint Aunis (Vic) (south), Maubourguet (south) http://mllidev.umbc.edu/gascon/English/documents/DocCaseDieuG. html

3. Coutumes de Mun. CoutMun, 1292.919 words. Mun (south) http://mllidev. umbc.edu/gascon/English/documents/CoutMunCAna.html

4. Notice historique sur La Réole. NotReoleD, 1230. 1156 words, La Réole (north) http://mllidev.umbc.edu/gascon/English/documents/NotReoleD.html

5. La Charte de Valcabrère. ChartValcabrA, 1318. 3838 words, Valcabrère (east) http://mllidev.umbc.edu/gascon/English/documents/ChartValcabrA.html

6. Coutumes de Castelnau-de-Rivière-Basse. CoutCastelnauM, 1309. 3669 words, Castelnau-de-Rivière-Basse (south) http://mllidev.umbc.edu/gascon/ English/documents/CoutCastelnauM.html

7. La Grande Charte de Saint-Gaudens. CoutSGaudensM, 1202. 4378 words, Saint-Gaudens (east) http://mllidev.umbc.edu/gascon/English/documents/ CoutSGaudensM.html

8. Second Cartulaire de l'abbaye de Sainte-Croix de Bordeaux. CartSCrD, 1244-1272. 14982 words. Bordeaux (north) http://mllidev.umbc.edu/gascon/ English/documents/CartSCrD.html

TLFi. Trésor de la Langue Française informatisé. Centre National de Ressources Textuelles et lexicales https://www.cnrtl.fr/definition/rien 